\title{
SOL-GEL SYNTHESIS OF ZINC CONTAINING
}

\section{CALCIUM PHOSPHATE BIOMATERIALS}

\section{PIERRE LAYROLLE, ATSUO ITO and TETSUYA TATEISHI}

Bionic Design Group

National Institute for Advanced Interdisciplinary Research

AIST, MITI, 1-1-4 Higashi, Tsukuba, Ibaraki 305, Japan

\begin{abstract}
Ca}_{3-\mathrm{x}} \mathrm{Zn}_{\mathrm{x}}\left(\mathrm{PO}_{4}\right)_{2}$ with $\mathrm{x}=0$ to 20 mole $\%$ was prepared by a sol-gel method starting from $\mathrm{Ca}(\mathrm{OEt})_{2}, \mathrm{H}_{3} \mathrm{PO}_{4}$ and $\mathrm{Zn}(\mathrm{OAc})_{2}$ reagents in ethanol. Amorphous and nanosized powders with controlled compositions were obtained. Crystallization into $\beta$ TCP occurred at about $600{ }^{\circ} \mathrm{C}$. Zinc substituted for calcium in the $\beta$-TCP structure up to $\mathrm{x}=12$ mole $\%$ as solid solution. For upper $\mathrm{x}$ values, the scholzite $\mathrm{CaZn_{2 }}\left(\mathrm{PO}_{4}\right)_{2}$ phase was detected. Powders were pressed and sintered into ceramics at $1100{ }^{\circ} \mathrm{C}$. Dense ceramics were obtained. EDAX revealed homogenous distributions of zinc, calcium and phosphorus.
\end{abstract}

\section{INTRODUCTION}

Calcium phosphate ceramics are widely used as biomaterials for damaged bones and teeth due to their chemical and structural resemblance with the mineral part of hard tissues. Indeed, calcium phosphate ceramics are not only biocompatible but also bioactive or resorbable. ${ }^{1}$ Furthermore, zinc is an essential trace element for human growth, being involved in many biological processes. Recently, zinc has been found to stimulate bone formation and bone growth in vivo and in vitro. ${ }^{2}$ Zinc could be preferably retained by tricalcium phosphate $\left[\beta-\mathrm{Ca}_{3}\left(\mathrm{PO}_{4}\right)_{2} ; \beta\right.$-TCP] among calcium phosphate ceramics, judging from its crystallographic and thermodynamic properties. ${ }^{3} \beta$-TCP ceramics are also gradually resorbed in the human body. ${ }^{1}$ Therefore, zinc containing $\beta$-TCP ceramics could release zinc gradually to stimulate bone growth. They could be considered as candidates for the next generation of bioceramics. The present study was undertaken to synthesize, through a new sol-gel process, ${ }^{4} \beta$-TCP including various amounts of zinc:

$$
3-x \mathrm{Ca}(\mathrm{OEt})_{2}+x \mathrm{Zn}(\mathrm{Ac})_{2}+2 \mathrm{H}_{3} \mathrm{PO}_{4} \stackrel{\mathrm{EtOH}}{\longrightarrow} \mathrm{Ca}_{3-x} \mathbf{Z n}_{x}\left(\mathbf{P O}_{4}\right)_{2} \downarrow+6-2 x \mathrm{EtOH}+2 x \mathrm{AcOEt}
$$




\section{EXPERIMENTAL PROCEDURE}

$\mathrm{Ca}-\mathrm{Zn}-\mathrm{PO}_{4}$ powders were precipitated in ethanol. A solution of $\mathrm{Ca}(\mathrm{OEt})_{2}$ was first obtained by reacting calcium with ethanol. Then, stoichiometric amounts of zinc acetate and $o$-phosphoric acid $(85 \%)$ solution were added to the $\mathrm{Ca}(\mathrm{OEt})_{2}$ solution in a reaction flask (Table 1). The $(\mathrm{Ca}+\mathrm{Zn}) / \mathrm{P}$ molar ratio of reagents was fixed at 1.50 while the $\mathrm{Zn} /(\mathrm{Ca}+\mathrm{Zn})$ ratio was increased from 0 to 20 mole $\%$. The precipitate was aged for 1 week at $25{ }^{\circ} \mathrm{C}$ under $\mathrm{N}_{2}$. Finally, gels were centrifuged at $4000 \mathrm{rpm}$ for $10 \mathrm{~min}$ and dried at $120{ }^{\circ} \mathrm{C}$ overnight. The powders were calcined at $850{ }^{\circ} \mathrm{C}$ for $5 \mathrm{~h}$ in air. TCP-xZn powders were mixed with binders (PEG \& PVA, $1 \& 3$ wt. \%) dried at $60{ }^{\circ} \mathrm{C}$ and sieved $(<75 \mu \mathrm{m})$. Powders $(0.8 \mathrm{~g})$ were pressed at $1000 \mathrm{~kg} / \mathrm{cm}^{2}$ into pellets $(\varnothing=16 \mathrm{~mm})$ and sintered into ceramics at $1100{ }^{\circ} \mathrm{C}$ for $5 \mathrm{~h}$.

The particle size distibution of gels was measured with a super dynamic laser scattering spectrophotometer (SDLS, Photal 7000) equipped with an Ar laser $(\lambda=488 \mathrm{~nm}$, $900 \mathrm{~mW}$, Spectra-Physics). Data were analyzed by the Marquadt method. X-ray diffraction (XRD) patterns of xerogels and calcined powders were recorded on a Rigaku RINT 2000 diffractometer with a $\mathrm{Cu} \mathrm{K}_{\alpha}$ radiation $(\lambda=1.5405 \AA ̊ A 0 \mathrm{kV}, 40 \mathrm{~mA})$. The texture of the ceramics was observed by a scanning electron microscope (SEM, Jeol JSM-6400) equipped with an EDAX analyzer.

TABLE 1. Preparation conditions of calcium zinc phosphate powders

\begin{tabular}{|c|c|c|c|}
\hline Samples & $\begin{array}{c}\text { Ca metal } \\
(\mathrm{g} ; \mathrm{mole})\end{array}$ & $\begin{array}{c}\mathrm{Zn}(\mathrm{OAc})_{2} .2 \mathrm{H}_{2} \mathrm{O} \\
\left(\mathrm{g} ; 10^{3} \text { mole }\right)\end{array}$ & $\begin{array}{c}\mathrm{H}_{3} \mathrm{PO}_{4}{ }^{b} \\
(\mathrm{~g} ; \mathrm{mole})\end{array}$ \\
\hline TCP & $12.06 ; 0.301$ & - & $23.04 ; 0.200$ \\
\hline TCP-0.1Zn & $11.99 ; 0.299$ & $0.071 ; 0.324$ & $23.05 ; 0.200$ \\
\hline TCP-0.5Zn & $11.95 ; 0.298$ & $0.332 ; 1.51$ & $23.07 ; 0.200$ \\
\hline TCP-1Zn & $11.89 ; 0.297$ & $0.662 ; 3.02$ & $23.11 ; 0.200$ \\
\hline TCP-5Zn & $11.40 ; 0.285$ & $3.294 ; 15.01$ & $23.05 ; 0.200$ \\
\hline TCP-10Zn & $10.81 ; 0.270$ & $6.595 ; 30.05$ & $23.05 ; 0.200$ \\
\hline TCP-12.5Zn & $10.61 ; 0.265$ & $7.685 ; 35.01$ & $23.08 ; 0.200$ \\
\hline TCP-15Zn & $10.21 ; 0.255$ & $9.881 ; 45.02$ & $23.07 ; 0.200$ \\
\hline TCP-20Zn & $9.61 ; 0.240$ & $13.175 ; 60.02$ & $23.04 ; 0.200$ \\
\hline
\end{tabular}

$a+800 \mathrm{ml}$ of ethanol. $b+200 \mathrm{ml}$ of ethanol. 


\section{RESULTS AND DISCUSSION}

Calcium zinc phosphates (TCP-xZn) were precipitated in ethanol starting from calcium ethylate, zinc acetate and $o$-phosphoric acid. The particle size distributions of the gels were measured by SDLS spectrophotometry. For both TCP and TCP-10Zn gels, nearly the same distribution was obtained as shown in Figure 1. The size distributions are centered at $70 \mathrm{~nm}$. The precipitation of nano-sized particles is due to the lowered solvatation of ethanol compared with water. The solubility of calcium phosphate strongly decreases in ethanol and hence, the crystal growth is inhibited. ${ }^{4}$ Moreover, XRD analysis revealed an amorphous nature for all the xerogels obtained and no other phases were detected. Therefore, the sol-gel synthesis yielded to amorphous and ultra-fine calcium zinc phosphate powders.

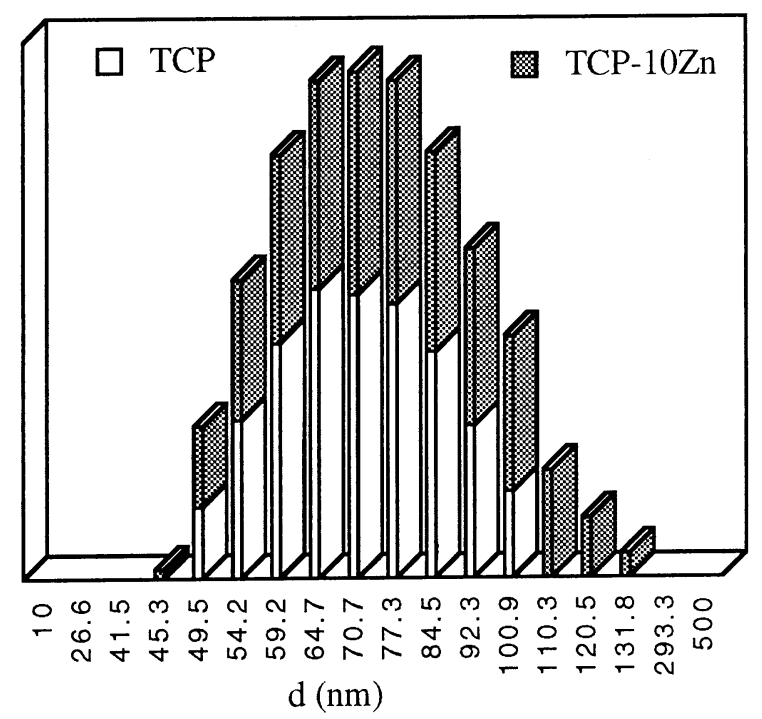

FIGURE 1. Particle size distributions of TCP and TCP-10Zn gels measured by SDLS.

The thermal behavior of calcium zinc phosphates was studied by XRD. For example, the XRD patterns of heated TCP-10Zn powder are shown in Figure 2. Up to $500{ }^{\circ} \mathrm{C}$, the powders remained amorphous. At higher temperatures, crystallization into the $\beta$-TCP phase occurred. Patterns of heated TCP-xZn showed a shift of XRD lines to higher angles with the uptake of zinc. This shift is due to the incorporation of zinc in the $\beta$-TCP structure. At higher $x$ values than 12 mole $\%$, scholzite $\left[\mathrm{CaZn}_{2}\left(\mathrm{PO}_{4}\right)_{2}\right]$ was detected. Therefore, amorphous TCP-xZn powders crystallized at around $700{ }^{\circ} \mathrm{C}$ and could form $\mathrm{Ca}_{3-\mathrm{x}} \mathrm{Zn}_{\mathrm{x}}\left(\mathrm{PO}_{4}\right)_{2}$ solid solution.

After calcination, the calcium zinc phosphate powders were easily pressed and sintered. For all the ceramics, calculated relative densities and measured shrinkage were 
about 95 and $15 \%$, respectively. EDAX maps revealed homogeneous distributions for calcium, zinc and phosphorus elements in the ceramics. Therefore, no chemical and phase segregation occurred during the sintering process.

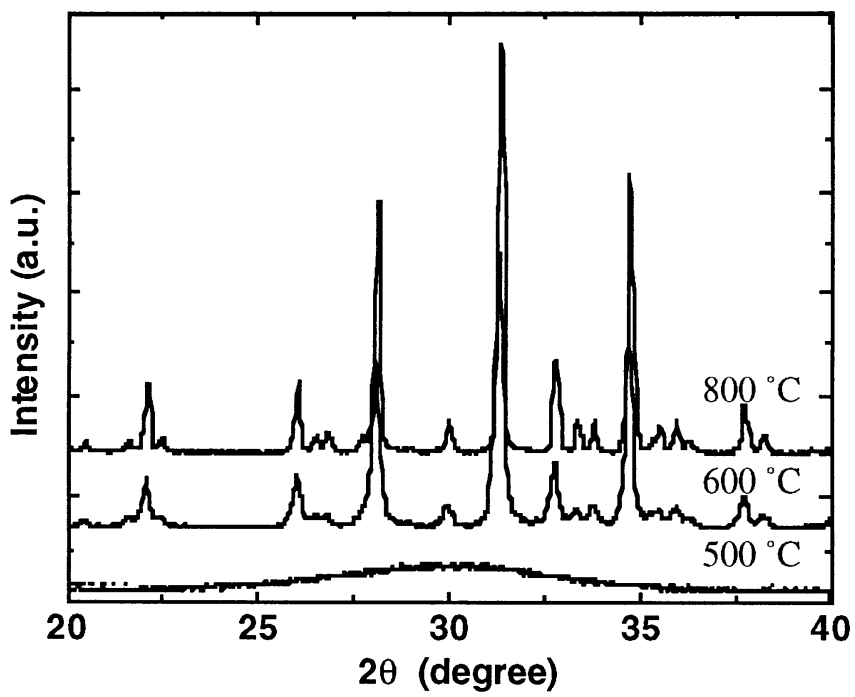

FIGURE 2. XRD patterns of TCP-10Zn powder heated at 500, 600 and $800{ }^{\circ} \mathrm{C}$.

\section{$\underline{\text { SUMMARY }}$}

The sol-gel process allows the preparation of amorphous and nano-sized zinc containing calcium phosphates. The powders crystallized at around $600{ }^{\circ} \mathrm{C}$ into the pure $\beta$-TCP phase. The incorporation of zinc in the structure gave stable $\mathrm{Ca}_{3-\mathrm{x}} \mathrm{Zn}_{\mathrm{x}}\left(\mathrm{PO}_{4}\right)_{2}$ solid solution. Powders are easily sintered into dense and homogenous $\beta$-TCZP ceramics. Hence, these new bioceramics could promote bone growth locally by releasing zinc into surrounding body fluid.

\section{AKNOWLEDGMENT}

P. Layrolle is supported by a fellowship from the Science \& Technology Agency of Japan.

\section{REFERENCES}

1 K. De Groot "Ceramics in Surgery" Ed. Elsevier: Amsterdam (1983).

2 M. Yamaguchi, H. Oishi and Y. Suketa, Biochem. Pharmacol., 36, 4007 (1987).

3 L. Schroeder, B. Dickens and W. E. Brown, J. Solid State Chem., 22, 253, (1977).

4 P. Layrolle and A. Lebugle, Chem. Mater., $\underline{6}, 1996$ (1994). 